\title{
An Exploration of the Green Targeting Strategy - Green Brand Positioning Strategy Linkage: A Qualitative Study
}

\author{
Mihai STOICA \\ The Bucharest University of Economic Studies, Bucharest, Romania \\ mihai.stoica.91@gmail.com
}

Received date:7 June 2021; Accepted date:2 September; Published date: 15 December 2021

Copyright (C) 2021. Mihai STOICA. Distributed under Creative Commons Attribution 4.0 International CC-BY 4.0

\begin{abstract}
The importance of the relation between targeting and positioning strategies is amplified in the context of the green market, as a result of the difficulty that many companies face in attracting an important customer base. The purpose of this paper is to provide a perspective on the relation between the targeting strategy and the green brand positioning strategy. The research method used was the in-depth individual interview, conducted among specialists from organic certified companies, who have in their portfolio a green brand which they sell on the organic food market in Romania. In order to provide an integrative view on the analyzed topic, the research was conducted among manufacturers, processors, distributors and retailers. The results showed that in the case of targeting the mass market, the selected positioning bases selected are mainly from the category of those specific to conventional products, while the importance of green positioning bases decreases (positioning at standards imposed by the legislation in force). On the other hand, if the company chooses to address only the segment of green consumers, then it is more likely that the company opts for those attributes and benefits that define green products (positioning above the standards imposed by the legislation in force). This paper offers a view on how to select the positioning bases needed to define the green brand positioning, taking into account the strategy chosen on a higher level (targeting strategy). Future studies could, through quantitative research, deepen and verify the relation between the proposed strategic alternatives for green brands.
\end{abstract}

Keywords: Green Brand Positioning, Green Marketing Strategies, Green Targeting Strategies, Organic Food Market.

\section{Introduction}

The extent to which a product meets the consumer's environmental requirements is essential for understanding the green marketing strategies, as it affects both the targeting strategy and the positioning strategy for green products (Driessen et al., 2013, p. 17). Thus, companies offering such products should be wary of the risk of

Cite this Article as : Mihai STOICA (2021), “An Exploration of the Green Targeting Strategy - Green Brand Positioning Strategy Linkage: A Qualitative Study ", Journal of Marketing Research and Case Studies, Vol. 2021 (2021), Article ID 127140, DOI : 10.5171/2021.127140 
over-emphasizing the green benefits over other benefits demanded by consumers. Consequently, based on the segmentation results, it may be suggested that various primary, secondary and tertiary benefits, including green benefits, should be selectively communicated to distinct segments to make the products desirable for the consumers (Yilmazsoy et al., 2015, pp. 998 - 999). Therefore, the choice of a certain targeting strategy should impact the intensity of the ecological component that defines the positioning bases chosen when elaborating the desired positioning.

\section{Literature Review}

\section{Targeting strategies adapted to the issue of green marketing}

In the context of the green market, the target market is "the degree to which a consumer segment that values green attributes is targeted, and it ranges from a small deep-green niche targeting to mass targeting" (Driessen et al., 2013, p. 5). In this regard, companies seeking to integrate environmental concerns into their marketing strategy can decide whether to address a niche market of "deep" green consumers (concentrated marketing strategy), to customize their offer of products so as to address consumers characterized by different levels of greenness (differentiated marketing strategy) or to try to penetrate the whole market, through mass marketing of green products (undifferentiated marketing strategy) (Belz and Karstens, 2005, p. 9; Dangelico and Vocalelli, 2017, pp. 1273 1274).

\section{Concentrated/niche marketing strategy}

Organizations that practice niche marketing understand what matters to people; they are aware of the cultural and societal changes and have a very clear view of the brand DNA (Gordon, 2002, p. 17). Therefore, some experts recommend that companies should consider the market for green products as a niche market and the consumers of these products as a niche segment (Orsato, 2006, p. 134; Andrews and DeVault, 2009, p. 326; Maniatis, 2016, p. 18).

Companies that focus on the eco-niche market, described by Schaltegger (2002) as bioneers, concentrate on research and development, and try to find customers with high preferences for their innovations in the green products sector (pp. 49 - 50). This strategic alternative involves targeting a precisely defined area of the market that is big enough to be economically successful and small enough to be neglected by the mass-market suppliers (p. 52).

Also, when an organization is selling a product with unique and new attributes, it can get the best results by targeting customers who understand the product or are willing to allocate time to learn about its benefits (Dean and Pacheco, 2014, p. $20)$. In addition, customers in this niche segment must be willing to pay premium prices for these environmentally friendly alternatives (Schaltegger, 2002, p. 52). This premium price may be imposed as an economic necessity when improving the eco-performance increases the costs; however, it can also be a result of a concentrated marketing strategy, irrespective of production costs (Peattie \& Charter, 2003, p. 737).

Cherian \& Jacob (2012, p. 118) consider that the development of green product markets is identified by organizations as an opportunity to improve niche marketing. Nevertheless, Belz (1999, cited in Merdin, 2011 , p. 13) questions the use of concentrated marketing in the case of green products (eco-niche), given that most consumers either do not have the sufficient income or are not prepared to pay premium prices or to incur additional costs in order to buy environmentally friendly products.

\section{Differentiated/segmented marketing strategy}

Regarding the green market, Roberts (1996, p. 218) observed that consumers react differently to green offers, so there is an opportunity for organizations to practice differentiated marketing, selling 
different products that benefit from a distinct communication, to different segments of consumers. Also, Jain and Kaur (2006, cited in Dangelico and Vocalelli, 2017, p. 1270) suggested that a single standardized green marketing program is not effective, highlighting the need to use a different green marketing strategy for each consumer segment. Thus, if differences are found, customers can be sorted into various green segments, and differential marketing strategies can be developed in order to market green ideas and products more efficiently and effectively to different groups of green customers (Jain and Kaur, 2004, p. 202).

In this way, some studies have recognized that there are segments of consumption with different levels of preference for green products (Laroche et al., 2001). Other studies even correlate the greening level of the product/organization with the decision to choose a certain targeting strategy (Driessen et al., 2013, p. 17). In this context, it is useful to segment the market according to the degree of consumer involvement in environmental protection.

This strategic alternative offers the organization the opportunity to differentiate its product offer, so as to address consumers characterized by different levels of involvement in environmental protection (Dangelico and Vocalelli, 2017, p. 1274). Thus, the organization may consider attracting market segments that include customers with various requirements not only in terms of environmental protection, but also in terms of the quality of purchased products or the level of satisfaction of personal benefits.

\section{Undifferentiated marketing/mass- marketing strategy}

Rettie et al. (2011, p.4) opine that organizations should target the whole market rather than a niche of it. Choosing a niche limits the sales potential, due to the fact that the offer is considered to be interesting only by green consumers. Experts believe this strategy to be an effective solution to change unsustainable behaviors and to orient consumers towards the consumption of green products. In fact, Vandermerwe and Oliff (1990, p. 1), ever since three decades ago, thought that green products are no longer specific only to niche markets, but have rather become increasingly suitable for the whole market.

Similarly, Belz (1999, cited in Merdin, 2011, pp. 12 - 13) believes that the greening of mass markets (instead of market niches) must be the main task of green marketing, because more sustainable markets may be obtained by better integrating environmental improvements. If the company's practices remain at the level of satisfying niche markets, the contribution to sustainability is likely to be marginal. Peattie and Charter (2003, p. 736) also believe that "in many industries, it will require the greening of the mass market to make a substantive contribution to sustainability". However, by targeting the mass market with environmentally advantageous innovations, there is a risk of losing that niche of consumers with strong ecological beliefs and also of failing to convince the large mass of customers with the offered benefits (Wüstenhagen, 1998, p. 20).

Therefore, companies have different options to make their market decisions in terms of the targeting strategy; however, they must take into account not only the greenness of the product (if it meets the requirements of environmentally conscious customers), the size of the company, financial resources and market position of the company, but also industry-specific factors (Belz, 2005, cited in Belz and Karstens, 2005, p. 9; Driessen et al., 2013, p. 1).

\section{Green Brand Positioning Strategy}

Green brand positioning "entails an active communication and differentiation of the brand from its competitors through its environmentally sound attributes" (Hartmann et al., 2005, p. 10). In order to choose the positioning for a brand, it is necessary to select the positioning bases that must be highlighted in order for that 
brand to be perceived by the public in the way the organization wants. In the case of green brands, the importance (intensity) of the green/ecological component (size) characterizing those positioning bases must be first determined.

Thus, the organization is in a position where it has to determine "the degree to which green attributes are used to communicate to the market how the product (or brand) differs from existing products" (Driessen et al., 2013, p. 5). Some specialists (Mera, 2003, p. 171; Belz and Karstens, 2005, pp. 10 - 11; Driessen et al., 2013, p. 13) believe that this decision involves establishing the need to position the green brand based on the combination between the green attributes (green positioning bases) and the traditional attributes, specific to conventional products, and determining which of the two categories of attributes (or benefits) is the dominant one. Therefore, the following strategic alternatives result:

A. Dominant presentation of the positioning bases specific to the ecological concerns of the organization: In this situation, the green positioning bases constitute the dimension of brand differentiation against competing brands (Hartmann et al., 2004, p. 86), these being located in the core of green brand positioning (Driessen et al., 2013, p. 5). Attributes, benefits or other positioning bases specific to a green product are the main elements that are communicated, before the benefits related to performance, costs or comfort (Belz and Karstens, 2005, pp. 10 - 11). However, in this situation, the innovation strategy of the organization will have to play an extremely important role (Driessen et al., 2013 , p. 13), because the elements on which the positioning is based must be constantly maintained at a higher level, so that consumers are satisfied with the choice they made. In addition, the superiority in the ecological field must be based on a standardized certification procedure that provides veracity to the elements underlying the green brand positioning (Sarkar, 2012, p. 44). The choice of this alternative is often recommended when the company chooses to exclusively target, through the green brand, a niche market represented by consumers who show a particular concern for environmental protection and consumption of green products (Yilmazsoy et al., 2015, pp. 998 - 999).

B. Balanced presentation between positioning bases specific to the ecological concerns of the organization and the traditional ones: In this case, the socioecological dimension is approached with the same intensity as the bases specific to conventional products, such as performance or advantageous price of products (Belz and Karstens, 2005, pp. 10 11). In this regard, Ottman et al. (2006, p. 24) state that a focus on the purely green attributes/benefits of products, without taking into account important value factors that increase the attractiveness of offers and meet the needs and interests of consumers may lead to green marketing myopia. Therefore, in the context of green brand positioning, it is necessary to analyze the need to achieve a balanced combination of attributes/benefits offered to consumers.

Ottman (2011, p. 114) points out the incorrect practice of many organizations that focus too much on green benefits at the expense of primary benefits. The most appropriate alternative indicated is to choose a combination of primary and green benefits, and to make the necessary efforts to integrate them into a relevant approach for the consumer. The opinion expressed by Mera (2003, p. 171) is in line with the view that positioning based only on the green attribute is usually not effective, because this attribute is neither the only nor the main attribute that the consumer demands at the time of the purchase decision. It can be assessed as a distinguishing feature of brands in the cases where there is no difference between the brands concerning other basic benefits, such as price, quality or comfort.

C. Dominant presentation of traditional
positioning bases: In this situation, the main
emphasis is on traditional benefits, while
green benefits are emphasized on a
secondary level (Mera, 2003, p. 171). 
Therefore, the socio-ecological dimension is only a flanking dimension that supports the price and performance of commodities. In this direction, Driessen et al. (2013, p. 17) found that green products/brands are not always positioned as green, an aspect influenced by the pre-chosen targeting strategy, namely the fact that it does not target a niche market.

Also, by reference to the organic food market in the European Union, the author of this paper identifies the possibility to achieve a delimitation of positioning strategies by relating to the standards imposed by the legislation in force, still taking into account the intensity of the ecological dimension. Thus, companies may decide to position the green brand either at the level of the standards imposed by the legislation in force (food must comply with Regulation EU 2018/848 in order to be considered organic) or above the standards imposed by the legislation in force - this alternative is often mentioned in the literature, being called "organic plus" positioning (Schleenbecker \& Hamm, 2013; Padel \& Gössinger, 2008; Gössinger et al., 2009).

\section{Research Methodology}

The purpose of this research is to investigate the relation between the targeting strategy and the positioning strategy in the case of green brands; more precisely to highlight how the green brand positioning is differently approached, depending on the targeting strategy chosen. The research topic was studied on the market of certified organic food products in Romania, a country where this market is still in the development phase. Since the subject of the targeting and positioning strategies for the brands present on the Romanian organic food market is very little represented in the specialized literature and the scientific researches, it is necessary to carry out an exploratory research.

The method of gathering information is the in-depth, semi-structured individual interview, conducted with the help of an interview guide, designed in advance.
The target population is made up of Romanian companies that have an organic certification granted by an accredited certification body, owning the property over a green brand or distributing exclusively an international green brand on the local market. The target population includes producers, processors, distributors and retailers. Even if the distributors of green brands do not have a significant involvement in establishing the positioning strategy (but rather in its communication), they were included in the investigated group because the Romanian market is dominated by green brands imported from other European Union countries (Stoica et al., 2020). Only thus can the research capture a clear and suggestive image of the analyzed marketing phenomenon. The research was conducted among professionals who have responsibilities in the field of marketing.

During the data collection stage, 25 interviews were conducted (13 producers/processors, 7 distributors and 5 retailers, out of which 3 were general retailers and 2 specialized retailers). The interviews were conducted between November 10, 2020 and February 23, 2021. For consultation, the transcript of the interviews is available upon request.

In order to respect the confidentiality of the companies participating in this research, as well as of the interviewed specialists, the following coding was used for interviews: IP - companies producing/processing organic food; ID companies distributing international green brands; IR.S - retailers specialized in the sale of organic food; and IR.G - general retailers.

The content analysis was performed using the MAXQDA software tool, which facilitated the analysis of the information obtained during the interviews. Taking into account the nature of the collected data, the author will not insist on statistical reporting in the data analysis. 


\section{Research Results}

\section{Identify the strategic targeting alternatives used by the companies included in the investigated group}

Targeting strategy is one of the most complex decisions faced by companies in the organic food market. This problem results from the poor knowledge of the size of the organic food market, which is also explainable to some extent, because a large number of participants reported a lack of data and information about this market. Therefore, most companies are unable to assess the size of the local market, and therefore assess the number of potential consumers.
At the beginning of the activity on this market, most companies choose to focus on attracting public consumers including intensive and occasional consumers of organic products; however, very few companies achieve the expected results. Along the way, many of the companies are put in the situation in which they are "forced" to "abandon" the segment represented by green consumers to expand the target audience, hoping that this could be one of the solutions to survive in the field of production and selling of organic food.

Based on the research results, a distinct profile of the companies included in the researched group was outlined, depending on the used strategic targeting alternative (Table 1).

Table 1: Targeting Strategy (TS) for companies included in the investigated group

\begin{tabular}{|c|c|c|}
\hline TS & The main coordinates of the companies' activity & $\begin{array}{c}\text { Representative } \\
\text { examples }\end{array}$ \\
\hline 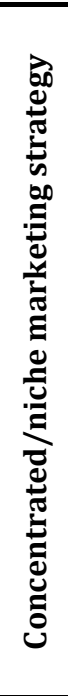 & $\begin{array}{l}\text { - A specific strategy is usually applied to small producers/processors, } \\
\text { who have in their portfolio products that differ significantly from the } \\
\text { rest of the green products present on the market; } \\
\text { - The offer consists of premium products, in some cases, these being } \\
\text { unique on the Romanian market, but not solely; } \\
\text { - The research-development activity is very developed; some of these } \\
\text { companies can be considered the pioneers of the green products } \\
\text { market; } \\
\text { - Companies with limited production capacity and/or limited raw } \\
\text { materials (some of them coming exclusively from their own sources) } \\
\text { choose to remain present only in a niche market. Also, the decision is } \\
\text { due to the fact that at this moment on the Romanian market, an } \\
\text { innovative green product (highly specialized) cannot be addressed to } \\
\text { the whole market; } \\
\text { - There is a concern in developing the brand equity, so these companies } \\
\text { prefer to choose the right strategies for an exclusive brand/niche } \\
\text { product (marketing channels used; refusal to produce for a retail brand } \\
\text { of a general retailer); }\end{array}$ & $\begin{array}{l}\text { - Processor of } \\
\text { canned organic } \\
\text { fruits, with } \\
\text { strong research } \\
\text { and development } \\
\text { activity (IP8); } \\
\text { - Producer of } \\
\text { packaged organic } \\
\text { vegetables and } \\
\text { fruits, with } \\
\text { production } \\
\text { throughout the } \\
\text { year (product } \\
\text { range adapted } \\
\text { according to the } \\
\text { season) (IP2); }\end{array}$ \\
\hline
\end{tabular}




\begin{tabular}{|c|c|c|}
\hline 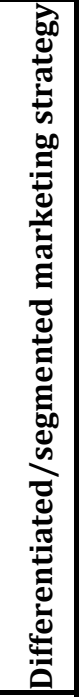 & $\begin{array}{l}\text { - A strategic alternative is difficult to apply in the case of the organic } \\
\text { food, due to the size of the local market. Therefore, when companies } \\
\text { make a specific offer for a certain segment, they do not refer only to } \\
\text { intensive or occasional consumers of green products (although they } \\
\text { represent the core target), but try to expand the target consumer } \\
\text { segment as well; } \\
\text { - Usually, this strategic alternative is chosen by medium-large } \\
\text { producers of organic food, with a wide range of products (but which } \\
\text { have only green products in their portfolio). The strategy is also } \\
\text { specific to distributors who manage to build an important portfolio of } \\
\text { products/brands, because they can easily cover several market } \\
\text { segments with them; } \\
\text { - A feasible strategy for specialized retailers develops representative } \\
\text { products for the most important segments, which they manage to } \\
\text { attract with the entire marketed offer; } \\
\text { - A strategy chosen to meet the various requirements of customers } \\
\text { concerned with environmental protection or the quality of the } \\
\text { products. }\end{array}$ & $\begin{array}{l}\text { - Producer of } \\
\text { organic wine, } \\
\text { with an } \\
\text { important } \\
\text { portfolio of } \\
\text { organic products, } \\
\text { organized by } \\
\text { several green } \\
\text { brands (IP9); } \\
\text { - Distributor of } \\
\text { international } \\
\text { green brands, in } \\
\text { particular from } \\
\text { France and Italy } \\
\text { (ID1); }\end{array}$ \\
\hline & $\begin{array}{l}\text { - It targets the whole market with the offer of organic food, in an } \\
\text { attempt to increase the number of green consumers; } \\
\text { - This alternative is used by many of the companies (producers, } \\
\text { processors, distributors) to generate a sales volume necessary to } \\
\text { maintain themselves on the market or due to the need to transform the } \\
\text { decision to target the organic market into a cost-effective approach; } \\
\text { - The offer does not have a high degree of specialization in terms of } \\
\text { green attributes, as attributes specific to conventional products are } \\
\text { rather developed. Thus, instead of focusing on the sustainable } \\
\text { development of the environment or the exclusive use of healthy } \\
\text { ingredients, companies focus on the needs of the whole market and } \\
\text { take into account the development of products that are manufactured } \\
\text { in large quantities and that are advantageous from an economic point } \\
\text { of view (the difference between the price of organic products and the } \\
\text { price of conventional products is smaller, longer shelf life, mass } \\
\text { production, etc.) } \\
\text { - Focuses, in particular, on the compliance with the minimum } \\
\text { standards imposed by the legislation in force for the production and } \\
\text { packaging; }\end{array}$ & $\begin{array}{l}\text { - Processor of } \\
\text { organic cereals, } \\
\text { flours and } \\
\text { bakery products } \\
\text { (IP3); } \\
\text { - Large producer } \\
\text { of conventional } \\
\text { and organic } \\
\text { dairy products } \\
\text { (IP11); } \\
\text { - Distributor of } \\
\text { international } \\
\text { green brands } \\
\text { (ID7); } \\
\text { - General retailer } \\
\text { (IR.G2); }\end{array}$ \\
\hline
\end{tabular}

Source: author's own study

\section{Differences in the substantiation of the green brand positioning strategy depending on the chosen targeting strategy}

Based on the analysis of the research results, a link was observed between the chosen targeting strategy and the brand positioning, from the perspective of the positioning bases used to define the desired positioning. Thus, if the desired approach is to target the mass market, then the positioning bases shall be chosen mainly from the category of those specific to conventional products, while the importance of bases characterized by a significant ecological component decreases. In this situation, companies resort to a positioning at the level of the standards imposed by the legislation in force. In most cases, only the indispensable visual elements (especially through the product packaging) are signaled.

Conversely, if the company chooses to address only the market of green consumers (intensive or occasional), then it is more likely to opt for those defining attributes and benefits of green products, requested by consumers who are very attentive to details and information about the particularities of consuming organic 
food (raw product; whole product; sugarfree product, foods that traditionally contain sugar; sustainable packaging which also does not affect the qualities of the product; and country of origin of raw materials). In this case, the green brand is positioned above the standards imposed by the legislation in force, managing to differentiate itself from most green brands on the market.

However, among these strategic options located at the extremes, presented in Table 2 , the author finds a number of alternatives that companies can use to synchronize the decisions related to the targeting strategy with the brand positioning strategy.

Observing the alternatives presented at extremes, it can be said that decisionmakers have options between the range of a positioning based mainly on traditional positioning bases (specific to conventional products), and a positioning where these bases are less important and those specific to green products are dominating. Between these two extremes, there are some other options and possibilities in terms of using a combination of available positioning bases, regardless of their category.

\section{Conclusions}

In order to provide a realistic basis for evaluating the research results, it is important to present the main limitations of this study. Due to the exploratory nature of the research, the results and conclusions of this study cannot be generalized at the level of the entire community formed by companies that are certified for being organic and that own/distribute at least one green brand sold on the Romanian market. However, referring to the size of the organic food market in Romania, the author appreciates that this research included a significant number of specialists from these companies, which leads to considering that the research results can be a solid information base for developing future research in this direction. In addition to the lack of possibility to generalize the research results, another limitation specific to the qualitative research is related to the role of the researcher in the research process. Thus, the subjectivity of the researcher, manifested involuntarily, can have a certain degree of influence, both in the data collection stage and in the data analysis and interpretation stage.

Choosing the right targeting strategy is probably one of the most complex decisions that companies in the market of organic food must face, which influences the number of future customers that the company could attract towards the brand. The decision on the targeting strategy influences the intensity of the elements of an ecological nature that are integrated in the green brand positioning strategy. Therefore, the green brand positioning can be established between two opposite alternatives: eco-friendly elements have a high intensity (strategic alternative chosen especially by brands targeting mainly the public of intensive or occasional consumers of organic food) or a low intensity in establishing the positioning strategy (especially brands targeting the general public; in this case, traditional attributes/benefits predominate in defining the positioning strategy). 
Table 2: Differences of the green positioning strategy depending on the chosen targeting strategy

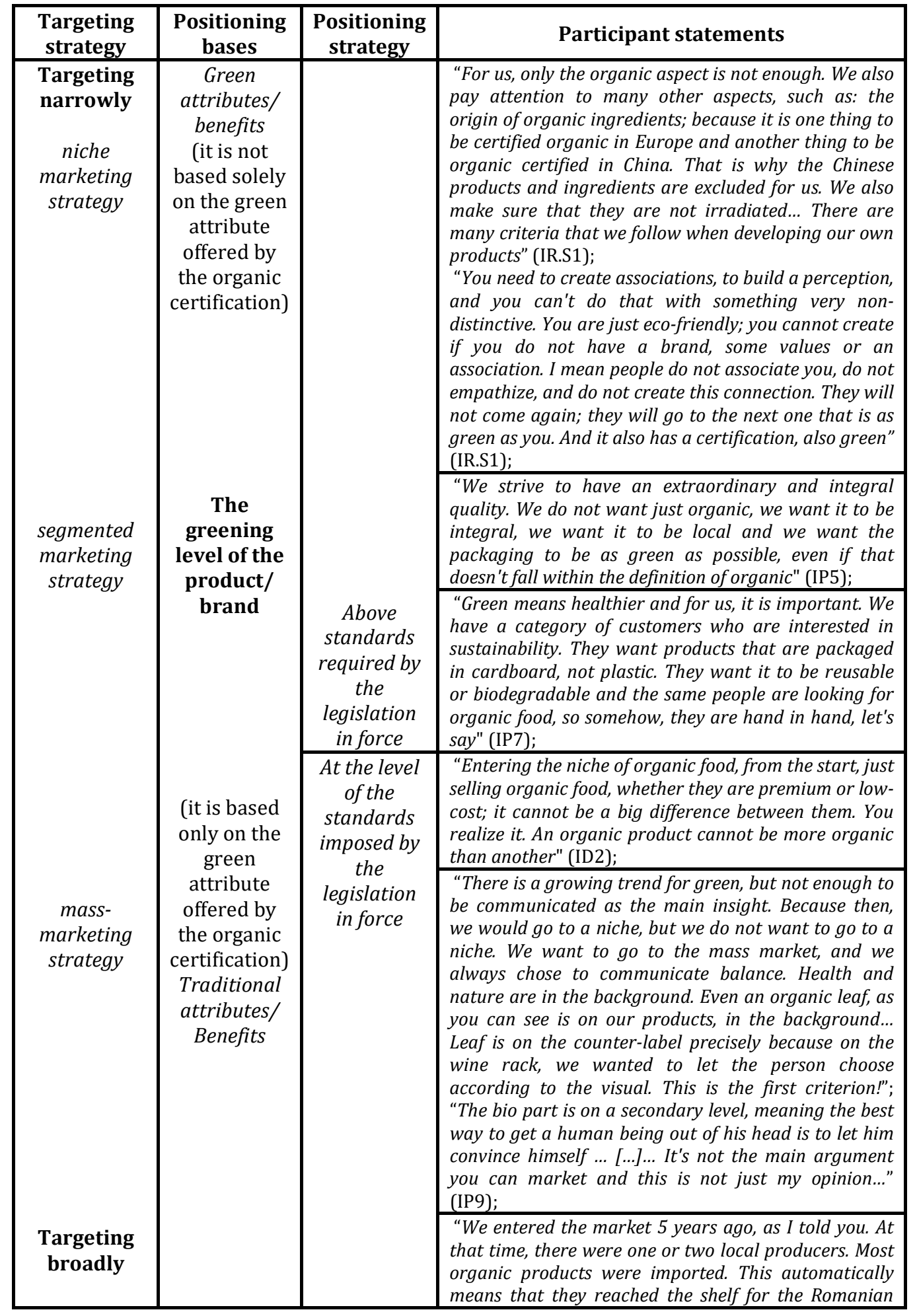




\begin{tabular}{|l|l|l|}
\hline 5 & $\begin{array}{l}\text { consumer with quite high prices and that was what we } \\
\text { wanted, to break the price barrier, and to succeed in } \\
\text { making the green categories accessible to all } \\
\text { Romanians. Basically, when we launched the range, we } \\
\text { did not focus on taking existing green consumers, but } \\
\text { to educate those who consume conventional products } \\
\text { and give them the opportunity to access this category. } \\
\text { In the years that followed, certainly due to our success, } \\
\text { there were several competitors who followed us, so } \\
\text { now it is a rather crowded market and the fight is } \\
\text { close" (IP1); }\end{array}$ \\
\hline
\end{tabular}

Source: author's own study

This decision also influences the strategic alternatives chosen to position the green brand. Therefore, depending on the level of standards imposed by the legislation in force, the positioning of the brand may be at the level of the standards imposed by the legislation in force (traditional attributes/benefits predominate, the point of differentiation being the green attribute and holding the EU mandatory certification) or above standards required by the legislation in force (attributes/benefits and other green positioning bases predominate, which are supported both by EU certification and, in some cases, by private bodies, such as Demeter certification).

\section{Acknowledgment}

This paper was co-financed by The Bucharest University of Economic Studies during the PhD program.

\section{References}

- Andrews, C. and DeVault, D. (2009) 'Green niche market development: A model with heterogeneous agents,' Journal of Industrial Ecology, 13(2), 326 - 345.

- Belz, F. M. and Karstens, B. (2005), 'Strategic and instrumental sustainability marketing in the Western European food processing industry: Conceptual framework and hypothesis,' Proceedings of the Corporate Responsibility Research Conference, 4 - 6 September 2005, University of Leeds, Leeds.

- Cherian, J. and Jacob, J. (2012) 'Green marketing: A study of consumers' attitude towards environment friendly products,' Asían Social Science, 8(12), 117 - 126.
- Dangelico, R. M. and Vocalelli, D. (2017) 'Green Marketing: an analysis of definitions, strategy steps, and tools through a systematic review of the literature,' Journal of Cleaner Production, Vol. 165, 1263 - 1279.

- Dean, T. J. and Pacheco, D. F. (2014) 'Green marketing: a strategic balancing act for creating value,' Journal of Business Strategy, 35(5), 14 - 22.

- Driessen, P. H., Hillebrand, B., Kok, R. and Verhallen, T. M. (2013) 'Green new product development: the pivotal role of product greenness,' IEEE Transactions on Engineering Management, 60(2), 315 - 326.

- Gordon, W. (2002) Brand green: mainstream or forever niche?, Green Alliance, London.

- Gössinger, K., Hametter, M. and Freyer, B. (2009) 'Ethical Oriented Activities Going Beyond Organic Standards In European Enterprises/Farms From Different Theoretical Perspectives,' Bioacademy 2009 Proceedings, 24 - 26 June 2009, Lednice na Moravě, Czech Republic, 75 - 79. - Hartmann, P., Apaolaza Ibáñez, V. and Forcada Sainz, F. J. (2004) 'Superando los límites medioambientales de la empresa: Un estudio experimental del efecto del posicionamiento ecológico en la actitud hacia la marca,' Cuadernos de Gestión, 4(1), 83 - 95.

- Hartmann, P., Ibanez, V. A. and Sainz, F. J. F. (2005) 'Green branding effects on attitude: functional versus emotional positioning strategies,' Marketing Intelligence \& Planning, 23(1), 9 - 29.

- Jain, S. K. and Kaur, G. (2004) 'Green marketing: An attitudinal and behavioural analysis of Indian consumers,' Global Business Review, 5(2), 187 - 205. 
- Jain, S. K. and Kaur, G. (2006) 'Role of socio-demographics in segmenting and profiling green consumers: an exploratory study of consumers in India,' Journal of International Consumer Marketing, 18(3), 107 - 146.

- Laroche, M., Bergeron, J. and BarbaroForleo, G. (2001) 'Targeting consumers who are willing to pay more for environmentally friendly products,' Journal of Consumer Marketing, 18(6), 503 - 520.

- Maniatis, P. (2016) 'Investigating factors influencing consumer decision-making while choosing green products,' Journal of Cleaner Production, Vol. 132, 215 - 228.

- Mera, A. C. (2003) 'El etiquetado ecológico: Un análisis de su utilización como instrumento de marketing' (Doctoral dissertation), Universidad de Extremadura, Badajoz.

- Merdin, E. (2011) 'Market-Driven Strategic Green Marketing Within The New Sustainability Paradigm,' Cambridge Business \& Economic Conference, 27 - 29 June 2011, Cambridge, United Kingdom, 1 29.

- Orsato, R. J. (2006) 'When does it pay to be green?,' California Management Review, 48(2), 127 - 143.

- Ottman, .J. A., Stafford, E. R. and Hartman, C. L. (2006) 'Avoiding green marketing myopia: Ways to improve consumer appeal for environmentally preferable products,' Environment Science and Policy for Sustainable Development, 48(5), 22 - 36.

- Ottman, J. (2011) The new rules of green marketing: strategies, tools, and inspiration for sustainable branding, Berrett-Koehler Publishers Inc., San Francisco.

- Padel, S. and Gössinger, K. (2008) 'Farmer consumer partnerships communicating ethical values: A conceptual framework,' CORE Organic Project Series Report, Tjele, Denmark.

- Peattie, K. and Charter, M. (2003), Green marketing, The Marketing Book, Baker, M.
J. (ed.), Butterworth-Heinemann, . Burlington.

- Roberts, J. A. (1996) 'Green consumers in the 1990s: profile and implications for advertising,' Journal of Business Research, 36(3), 217 - 231.

- Sarkar, A. N. (2012) 'Green branding and eco-innovations for evolving a sustainable green marketing strategy' Asia-Pacific Journal of Management Research and Innovation, 8(1), 39 - 58.

- Schaltegger, S. (2002) 'A Framework for Ecopreneurship: Leading Bioneers and Environmental Managers to Ecopreneurship,' Greener Management International, Vol. 38, 45 - 58.

- Schleenbecker, R. and Hamm, U. (2013) 'Consumers' perception of organic product characteristics. A review,' Appetite, Vol. 71, 420 - 429.

- Stoica, M., Mehedințu, M., Stoian, M., Stancu, A., Filip, A., and Roșca, M. I. (2020), 'The Organic Food Market in Romania', Emerging Trends in Marketing and Management International Conference, 25 27 June 2020, University of Economic Studies Publishing House, Bucharest.

- Vandermerwe, S. and Oliff, M. D. (1990) 'Customers drive corporations,' Long range planning, 23(6), 10 - 16.

- Wüstenhagen, R., (1998), 'Pricing strategies on the way to ecological mass markets,' Greening of Industry Network Conference, 15-18 November 1998, University of St. Gallen, St. Gallen, Switzerland, $1-24$.

- Yilmazsoy, B., Schmidbauer, H. and Rösch, A. (2015) 'Green segmentation: cross-national study,' Marketing Intelligence \& Planning, 33(7), 981 - 1003. 